\title{
Effect of tannins and cellulase on growth performance, nutrients digestibility, blood profiles, intestinal morphology and carcass characteristics in Hu sheep
}

\author{
M. D. Zhao' ${ }^{1}$, L. F. Di', Z. Y. Tang ${ }^{1}$, W. Jiang ${ }^{1}$, and C. Y. Li ${ }^{1,2, *}$
}

\begin{abstract}
* Corresponding Author: C. Y. Li
Tel: +86-0431-2435519, Fax: +86-0431-2435519,

E-mail: licy@ybu.edu.cn
\end{abstract}

'Department of Animal Science, Agricultural College of Yanbian University, Jilin 133002, China

${ }^{2}$ Innovation Center of Beef Cattle Science and

Industry Technology, Yanbian University, Jilin 133002, China

ORCID

M. D. Zhao

https://orcid.org/0000-0003-0845-8270

L. F. Di

https://orcid.org/0000-0002-7269-8394

Z. Y. Tang

https://orcid.org/0000-0001-9109-3166

W. Jiang

https://orcid.org/0000-0003-2134-2053

C. Y. Li

https://orcid.org/0000-0002-9496-3494

Submitted Dec 4, 2018; Revised Feb 11, 2019; Accepted Feb 27, 2019
Objective: This study was conducted to evaluate the effects of tannins and cellulase on growth performance, nutrient digestibility, blood profiles, intestinal morphology, and carcass characteristics in Hu sheep.

Methods: A total of 48 three-month-old meat Hu sheep $(25.05 \pm 0.9 \mathrm{~kg})$ were blocked based on body weight, and randomly allotted to 4 treatments with 3 replicates of 4 sheep each. The experiment lasted for $80 \mathrm{~d}$, and dietary treatments were as follows: i) CON, control diet; ii) TAN, CON $+0.1 \%$ tannins; iii) CEL, CON $+0.1 \%$ cellulase; iv) TAN+CEL, CON $+0.1 \%$ tannins and $0.1 \%$ cellulase.

Results: Compared with CON, CEL, and TAN+CEL had greater $(\mathrm{p}<0.05)$ final body weight (FBW) and average daily gain but lower $(\mathrm{p}<0.05)$ feed conversion ratio, while FBW of TAN+ CEL was lower $(\mathrm{p}<0.05)$ than that of CEL. The apparent total tract digestibility (ATTD) of dry matter in TAN, CEL, and TAN+CEL groups were higher $(\mathrm{p}<0.05)$ than that in CON. CEL and TAN+CEL groups had greater $(p<0.05)$ ATTD of crude fiber compared with TAN and CON, while TAN group had lower $(\mathrm{p}<0.05)$ ATTD of crude protein than other treatments. TAN, CEL, and TAN+CEL groups increased $(\mathrm{p}<0.05)$ serum globulin and alkaline phosphatase but decreased $(\mathrm{p}<0.05)$ albumin/globulin. Serum total protein was greatest for TAN+CEL, intermediate for TAN and CEL and least for CON $(p<0.05)$. TAN+CEL group increased $(\mathrm{p}<0.05)$ dressing percentage compared with $\mathrm{CON}$, while the backfat thickness of CEL was lower $(\mathrm{p}<0.05)$ than that of CON. The villus height of jejunum and ileum in CEL and TAN+CEL groups were greater $(\mathrm{p}<0.05)$ than that in CON, and the crypt depth and villus height: crypt depth of jejunum were increased $(p<0.05)$ in TAN, CEL, and TAN+CEL groups.

Conclusion: The addition of tannins and cellulase together promoted nutrient digestion, liver protein synthesis and intestinal development and thus improved growth performance and carcass characteristics.

Keywords: Tannins; Cellulase; Growth Performance; Nutrient Digestibility; Blood Profiles; Intestinal Morphology

\section{INTRODUCTION}

Tannins are a group of polyphenolic compounds generally occurring in the forages consumed by ruminants [1]. Researches have shown that tannins improved protein utilization in ruminants because they could complex with the proteins and protect them from degradation, and then release the protein later in the intestine [2]. Therefore, the amount of high-quality protein available to ruminants for absorption would be increased [3]. Moreover, feeding tannin-containing forages or tannins supplementation reduced $\mathrm{CH}_{4}$ and $\mathrm{N}_{2} \mathrm{O}$ emissions and increased the amount of energy available to the ruminants. It is reported that 
tannins could reduce total methanogen populations and methane emissions [4].

In ruminants, fiber digestion was a limiting factor in nutrient utilization and ruminant production systems [5]. Exogenous cellulase supplementation has been proved to be an effective mean of improving nutrient utilization of forages and yielding more metabolizable energy for ruminants [5]. Previous studies demonstrated that although the results were inconsistent, the addition of cellulase could increase nutrient digestibility and feed conversion [6].

However, tannins could interact with the cell wall and secrete catabolic enzymes and then inhibit cellulolytic microorganisms in the rumen, and ultimately reduce the secretion of cellulase [7]. Moreover, previous study proved that tannins presented enzyme-specific interactions with cellulase to inhibit its activity. As a result, fiber digestion would be interfered by tannins [8].

An in vitro experiment showed that cellulase addition decreased soluble tannins and condensed tannins with increasing enzyme inclusions [9], which might counteract the reduction of cellulase. However, reports about the effects of tannins or cellulase alone or together on sheep were very limited. Thus, we hypothesized that the addition of tannins and cellulase together might have a beneficial effect in sheep. Therefore, the objective of this study was to determine the effects of tannins and cellulase on growth performance, nutrients digestibility, blood profiles, intestinal morphology and carcass characteristics in $\mathrm{Hu}$ sheep.

\section{MATERIALS AND METHODS}

\section{Animals, diets, and treatments}

All animal experiment procedures in this study were approved by the Institutional Animal Care and Use Committee of Yanbian University. The experiment was conducted at Animal Husbandry Research Institute of Yanbian Academy of Agricultural Sciences from May 2018 to September 2018. A total of 48 three-month-old meat Hu sheep $(25.05 \pm 0.9 \mathrm{~kg})$ were blocked based on body weight and randomly allocated into 4 treatments with 3 pens per treatment and 4 sheep per pen. Prior to the experiment, the animals were treated against internal and external parasites. Experimental treatments included: i) $\mathrm{CON}$, control diet; ii) TAN, CON $+0.1 \%$ tannins ( $95 \% \mathrm{pu}-$ rity); iii) CEL, CON+0.1\% cellulase ( $15,000 \mathrm{IU} / \mathrm{g})$; iv) TAN+ CEL, CON $+0.1 \%$ tannins and $0.1 \%$ cellulase. After an adaptation period of 14 days to the experimental conditions, the sheep stayed for $80-\mathrm{d}$ feeding trial. Diets were formulated to provide all the nutrients to meet or exceed NRC requirements [10]. All diets were kept at a concentrate: roughage ratio of 50:50, where the roughage component was maize straws and the concentrate consisted of corn, wheat bran, soybean meal and premix (Table 1). The diets were offered
Table 1. Dietary ingredients and calculated nutritional composition of the control diet

\begin{tabular}{lc}
\hline Item & Content \\
\hline Ingredient (\% of DM) & \\
Corn & 60 \\
Wheat bran & 11 \\
Soybean meal & 27 \\
Premix) & 2 \\
Chemical composition (\% of DM) & \\
ME (MJ/kg) & 9.48 \\
CP & 18.71 \\
Ca & 0.50 \\
P & 0.46 \\
\hline
\end{tabular}

$\mathrm{DM}$, dry matter; $\mathrm{ME}$, metabolizable energy; $\mathrm{CP}$, crude protein.

1) Each kilogram contains: vitamin A 100,000 IU; vitamin $D_{3} 80,000$ IU; vitamin E, $700 \mathrm{IU}$; iron, $3.5 \mathrm{~g}$; copper, $0.9 \mathrm{~g}$; manganese $3 \mathrm{~g}$; zinc, $5.5 \mathrm{~g}$; iodine, $60 \mathrm{mg}$; selenium, 30 mg; cobalt, 45 mg; calcium, 20\%; total phosphorus, 3.5\%; chloride sodium, $30 \%$.

to the animals in two equal halves at 7:30 and 15:30 daily. Animals were allowed ad libitum access to feed and water throughout the experiment.

\section{Growth performance}

The sheep were weighed individually on $\mathrm{d} 1$ and 80 of the experiment. Average daily gain (ADG) was calculated by the difference between final body weight (FBW) and initial body weight. Feed offered and refused was quantified daily for each pen to calculate average daily feed intake (ADFI). Feed conversion ratio $(\mathrm{F} / \mathrm{G})$ was calculated as a ratio of $\mathrm{ADFI}$ to ADG.

\section{Nutrient digestibility}

Digestibility trial was conducted at the end of the feeding trial and feces were collected daily for 6 days from a fecal collection bag attached to the sheep. The feces were weighed and mixed, and $25 \%$ of representative samples were taken and frozen at $-20^{\circ} \mathrm{C}$. At the end of the collection period, all samples of each sheep were pooled and $25 \%$ of the composite sample was taken and dried at $65^{\circ} \mathrm{C}$ for $72 \mathrm{~h}$. Daily feed per animal was also collected. The chemical analysis of feces and feed were performed to determined dry matter (DM), crude protein $(\mathrm{CP})$, ether extract $(\mathrm{EE})$, crude fiber $(\mathrm{CF})$ and ash according to standard AOAC method [11]. Apparent total tract digestibility (ATTD) of DM and other nutrients was determined as a percentage of the nutrient intake not recovered in the feces.

\section{Blood profiles}

At the end of feeding trial, blood samples $(10 \mathrm{~mL})$ via the jugular vein were collected from three sheep from each treatment. The blood samples were stored at $-4^{\circ} \mathrm{C}$ and then submitted for biochemical parameters analysis. The albumin (ALB), globu- 
lin (GLB), albumin/globulin (A/G), total protein (TP), total cholesterol (TC), triglyceride (TG), alanine transaminase (ALT), alkaline phosphatase (ALP), glucose (GLU) concentrations were determined by an automatic biochemistry analyzer (Hitachi Model 7600, Tokyo, Japan).

\section{Carcass characteristics}

After blood collection, the same sheep were weighted and euthanized with an intravenous injection of $200 \mathrm{mg} / \mathrm{kg}$ of body weight (BW) sodium pentobarbital (Sigma Chemical Co., St. Louis, MO, USA) after $24 \mathrm{~h}$ fasting. Decapitation and skinning of the sheep were undertaken after removing legs below the hock and knee joints. The carcass weight was checked after removing thoracic, abdominal and pelvic contents, and the organs (heart, liver, lungs, and kidneys) were weighed. Dressing percentage was calculated as carcass weight divided by the live body weight. The carcass was split between 12th and 13th ribs perpendicular to the backbone to measure the cross section of rib eye muscle area and the backfat thickness over the maximum muscle depth at same site was also recorded.

\section{Tissue collection and measurement}

After abdominal contents collection, 2 to $2.5 \mathrm{~cm}$ longitudinal sections of jejunum and ileum were taken from $5 \mathrm{~cm}$ distal to the duodenojejunal junction and jejunoileal junction separately. All samples were soaked in 4\% paraformaldehyde fix solution immediately and then embedded in paraffin and sectioned ( 3 to $5 \mu \mathrm{m}$ ). Slides were stained with hematoxylin and eosin (H\&E) as described in Holle et al [12], then digitized and measured by a fluorescence microscope camera via DP2-BSW software (Olympus, Tokyo, Japan). The crypt depth (CD), villus height $(\mathrm{VH})$, and $\mathrm{VH}: \mathrm{CD}$ ratio was measured according to methods described by McLeod et al [13]. For each section, 12 of the most representative villi and crypt were used for measurement.

Statistical analysis

Data were analyzed using the general linear model Procedure of SAS as a randomized complete block design (SAS Inst. Inc., Cary, NC, USA) with the pen being considered as the experimental unit. The average initial BW was used as a covariate for ADFI and ADG. Differences among treatment means were determined using Tukey's range test. Variability in the data was expressed as the standard error means and a probability level of $\mathrm{p}<0.05$ was considered statistically significant.

\section{RESULTS}

\section{Growth performance}

CEL and TAN+CEL groups increased $(\mathrm{p}<0.05)$ FBW compared with CON, and the FBW of CEL group was higher ( $\mathrm{p}<$ 0.05 ) than that of TAN+CEL group (Table 2). ADG did not differ $(p>0.05)$ between CEL and TAN+CEL group but both were higher than CON and TAN group $(p<0.05)$. There were no significant differences in ADFI among treatments ( $\mathrm{p}>0.05)$. $\mathrm{F} / \mathrm{G}$ of CEL group was lower $(\mathrm{p}<0.05)$ than that of $\mathrm{CON}$ group. TAN and TAN+CEL groups had no significant effects on F/G compared with CON.

\section{Nutrient digestibility}

ATTD of DM in TAN, CEL and TAN+CEL groups were greater $(\mathrm{p}<0.05)$ than that in CON (Table 3). CEL and TAN+CEL groups had higher $(\mathrm{p}<0.05)$ ATTD of CF compared with TAN and CON, while TAN group had lower $(\mathrm{p}<0.05)$ ATTD of $\mathrm{CP}$ than other treatments. ATTD of EE or ash did not differ ( $p>0.05)$ among groups.

\section{Blood profiles}

Compared with CON, TAN, CEL, and TAN+CEL groups increased $(\mathrm{p}<0.05)$ serum GLB and ALP but decreased ( $\mathrm{p}<$ 0.05) A/G (Table 4). TP was greatest for TAN+CEL group, intermediate for TAN and CEL group, and least for CON $(p<0.05)$. No differences were observed $(p>0.05)$ in ALB, TC, TG, ALT, or GLU among treatments.

\section{Intestinal morphology}

The VH of jejunum and ileum in CEL and TAN+CEL groups

Table 2. Effects of tannins and cellulase on growth performance in Hu sheep"

\begin{tabular}{lcccccc}
\hline Item & CON $^{2)}$ & TAN $^{2)}$ & CEL $^{2)}$ & TAN+CEL $^{2)}$ & SEM & p-value \\
\hline IBW (kg) & 25.17 & 25.50 & 25.30 & 24.23 & 0.45 & 0.76 \\
FBW (kg) & $35.70^{\mathrm{c}}$ & $36.40^{\mathrm{bc}}$ & $38.37^{\mathrm{a}}$ & $37.27^{\mathrm{b}}$ & 0.50 & 0.04 \\
ADG (g) & $131^{\mathrm{b}}$ & $136^{\mathrm{b}}$ & $163^{\mathrm{a}}$ & $163^{\mathrm{a}}$ & 5.2 & 0.03 \\
ADFI (g) & 2,161 & 2,172 & 2,233 & 2,290 & 52 & 0.37 \\
F/G & $16.44^{\mathrm{a}}$ & $15.94^{\mathrm{ab}}$ & $13.66^{\mathrm{b}}$ & $14.14^{\mathrm{ab}}$ & 0.68 & 0.04 \\
\hline
\end{tabular}

SEM, pooled standard error of the means; IBW, initial body weight; FBW, final body weight; ADG, average daily gain; ADFI, average daily feed intake; F/G, feed conversion ratio.

1) Each mean represents 3 replications with 4 sheep per replication.

${ }^{2)}$ CON, control diet; TAN, CON+0.1\% tannins ( $95 \%$ purity); CEL, CON+0.1\% cellulose $(15,000 \mathrm{IU} / \mathrm{g}) ;$ TAN+ CEL, CON+0.1\% tannins and $0.1 \%$ cellulase.

${ }^{a-c}$ Mean values within a row marked with different superscript letters differ significantly at $p<0.05$. 
Table 3. Effects of tannins and cellulase on nutrient digestibility in Hu sheep ${ }^{1)}$

\begin{tabular}{lcccccc}
\hline Item (\%) & CON $^{2)}$ & TAN $^{2)}$ & CEL $^{2)}$ & TAN+CEL $^{2)}$ & SEM & p-value \\
\hline DM & $64.47^{\mathrm{b}}$ & $65.67^{\mathrm{a}}$ & $66.57^{\mathrm{a}}$ & $66.27^{\mathrm{a}}$ & 0.38 & 0.03 \\
CP & $64.34^{\mathrm{a}}$ & $61.33^{\mathrm{b}}$ & $64.50^{\mathrm{a}}$ & $64.03^{\mathrm{a}}$ & 0.36 & 0.04 \\
EE & 53.63 & 54.20 & 54.37 & 54.43 & 0.26 & 0.56 \\
CF & $60.97^{\mathrm{b}}$ & $60.37^{\mathrm{b}}$ & $64.07^{\mathrm{a}}$ & $63.50^{\mathrm{a}}$ & 0.40 & 0.03 \\
ASH & 14.27 & 14.47 & 14.47 & 14.57 & 0.28 & 0.61 \\
\hline
\end{tabular}

SEM, pooled standard error of the means; DM, dry matter; $C P$, crude protein; EE, ether extract; $C F$, crude fiber; $A S H$, ash.

1) Each mean represents 3 replications with 4 sheep per replication.

2) CON, control diet; TAN, CON+0.1\% tannins ( $95 \%$ purity); CEL, CON+0.1\% cellulose $(15,000 \mathrm{IU} / \mathrm{g})$; TAN+CEL, CON $+0.1 \%$ tannins and $0.1 \%$ cellulase.

$a, b$ Mean values within a row marked with different superscript letters differ significantly at $p<0.05$.

Table 4. Effects of tannins and cellulase on blood profiles in Hu sheep ${ }^{1)}$

\begin{tabular}{|c|c|c|c|c|c|c|}
\hline Item & $\mathrm{CON}^{2)}$ & TAN $^{2)}$ & $\mathrm{CEL}^{2)}$ & $\mathrm{TAN}+\mathrm{CEL}^{2)}$ & SEM & $\mathrm{p}$-value \\
\hline $\operatorname{ALB}(g / L)$ & 30.46 & 29.89 & 29.37 & 29.45 & 0.84 & 0.38 \\
\hline GLB (g/L) & $28.58^{b}$ & $32.19^{a}$ & $34.85^{\mathrm{a}}$ & $32.44^{\mathrm{a}}$ & 0.69 & 0.02 \\
\hline$A / G$ & $1.07^{\mathrm{a}}$ & $0.93^{b}$ & $0.84^{b}$ & $0.91^{b}$ & 0.03 & 0.03 \\
\hline $\mathrm{TP}(\mathrm{g} / \mathrm{L})$ & $61.47^{c}$ & $64.00^{b}$ & $63.38^{b}$ & $67.78^{a}$ & 0.81 & 0.02 \\
\hline TC (mmol/L) & 1.57 & 1.52 & 1.57 & 1.55 & 0.04 & 0.77 \\
\hline TG (mmol/L) & 0.42 & 0.41 & 0.45 & 0.37 & 0.05 & 0.50 \\
\hline ALT (U/L) & 21.51 & 23.56 & 24.94 & 23.62 & 3.04 & 0.42 \\
\hline $\operatorname{ALP}(\mathrm{U} / \mathrm{L})$ & $250.5^{b}$ & $280.9^{\mathrm{a}}$ & $286.2^{\mathrm{a}}$ & $294.9^{\mathrm{a}}$ & 8.24 & 0.03 \\
\hline GLU (mmol/L) & 3.47 & 3.51 & 3.51 & 3.47 & 0.04 & 0.62 \\
\hline
\end{tabular}

SEM, pooled standard error of the means; ALB, albumin; GLB, globulin; A/G, albumin/globulin; TP, total protein; TC, total cholesterol; TG, triglyceride; ALT, alanine transaminase; ALP, alkaline phosphatase; GLU, glucose.

1) Each mean represents 3 replications with 1 sheep per replication.

2) CON, control diet; TAN, CON+0.1\% tannins (95\% purity); CEL, CON $+0.1 \%$ cellulose $(15,000 \mathrm{IU} / \mathrm{g})$; TAN+CEL, CON $+0.1 \%$ tannins and $0.1 \%$ cellulase.

a,b Mean values within a row marked with different superscript letters differ significantly at $p<0.05$.

was greater $(\mathrm{p}<0.05)$ than that in $\mathrm{CON}$, and no differences were observed ( $p>0.05)$ between TAN and CON (Table 5). Compared with CON, the $\mathrm{CP}$ and $\mathrm{VH}: \mathrm{CD}$ of jejunum were increased $(\mathrm{p}<0.05)$ in TAN, CEL, and TAN+CEL groups. However, no significant differences in the $\mathrm{CD}$ and VH:CD were found ( $p>0.05)$ for the ileum.

\section{Carcass characteristics}

The slaughter body weight of CEL group was higher $(\mathrm{p}<0.05)$ than that of $\mathrm{CON}$ and no differences were observed $(\mathrm{p}>0.05)$ among the other three groups (Table 6). The carcass weight did not $(\mathrm{p}>0.05)$ differ between CEL and TAN+CEL group but both were greater than CON $(\mathrm{p}<0.05)$. TAN+CEL group significantly increased $(\mathrm{p}<0.05)$ dressing percentage com-

Table 5. Effects of tannins and cellulase on intestinal morphology in Hu sheep ${ }^{1)}$

\begin{tabular}{lcccccc}
\hline Item & CON $^{2)}$ & TAN $^{2)}$ & CEL $^{2)}$ & TAN+CEL & SEM & p-value \\
\hline $\begin{array}{l}\text { Villus height }(\mu \mathrm{m}) \\
\quad \text { Jejunum }\end{array}$ & $522.8^{\mathrm{c}}$ & $530.7^{\mathrm{ab}}$ & $544.3^{\mathrm{a}}$ & $540.8^{\mathrm{bc}}$ & 5.43 & 0.04 \\
$\quad$ Ileum & $492.3^{\mathrm{c}}$ & $505.0^{\mathrm{ab}}$ & $508.6^{\mathrm{b}}$ & $525.0^{\mathrm{a}}$ & 4.25 & 0.03 \\
$\begin{array}{l}\text { Crypt depth }(\mu \mathrm{m}) \\
\quad\end{array}$ & & & & & \\
$\quad$ Jejunum & $240.0^{\mathrm{a}}$ & $217.7^{\mathrm{b}}$ & $220.8^{\mathrm{b}}$ & $223.8^{\mathrm{b}}$ & 4.87 & 0.03 \\
$\quad$ leum & 214.9 & 213.2 & 207.6 & 210.8 & 5.26 & 0.39 \\
$\quad \begin{array}{l}\text { Villus height/crypt depth } \\
\text { Jejunum }\end{array}$ & $2.18^{\mathrm{a}}$ & $2.44^{\mathrm{b}}$ & $2.47^{\mathrm{b}}$ & $2.42^{\mathrm{b}}$ & 0.06 & 0.03 \\
$\quad$ Ileum & 2.31 & 2.36 & 2.45 & 2.49 & 0.07 & 0.53 \\
\hline
\end{tabular}

SEM, pooled standard error of the means.

1) Each mean represents 3 replications with 1 sheep per replication.

2) CON, control diet; TAN, CON+0.1\% tannins ( $95 \%$ purity); CEL, CON+0.1\% cellulose $(15,000 \mathrm{IU} / \mathrm{g}) ; \mathrm{TAN}+\mathrm{CEL}, \mathrm{CON}+0.1 \%$ tannins and $0.1 \%$ cellulase.

${ }^{a-c}$ Mean values within a row marked with different superscript letters differ significantly at $p<0.05$. 
Table 6. Effects of tannins and cellulase on carcass characteristics in Hu sheep ${ }^{1)}$

\begin{tabular}{|c|c|c|c|c|c|c|}
\hline Item & $\mathrm{CON}^{2)}$ & TAN $^{2)}$ & $\mathrm{CEL}^{2)}$ & $\mathrm{TAN}+\mathrm{CEL}^{2)}$ & SEM & p-value \\
\hline Slaughter body weight $(\mathrm{kg})$ & $35.60^{b}$ & $36.60^{\mathrm{ab}}$ & $38.40^{\mathrm{a}}$ & $37.40^{\mathrm{ab}}$ & 0.98 & 0.03 \\
\hline Carcass weight $(\mathrm{kg})$ & $16.01^{c}$ & $17.12^{\mathrm{bc}}$ & $19.11^{\mathrm{ab}}$ & $19.91^{\mathrm{a}}$ & 0.74 & 0.02 \\
\hline Dressing percentage (\%) & $44.97^{b}$ & $46.79^{\mathrm{ab}}$ & $49.75^{a b}$ & $53.27^{\mathrm{a}}$ & 2.25 & 0.04 \\
\hline Backfat thickness (cm) & $1.20^{\mathrm{a}}$ & $0.67^{b}$ & $0.80^{\mathrm{ab}}$ & $1.03^{\mathrm{ab}}$ & 0.19 & 0.03 \\
\hline Eye muscle area $\left(\mathrm{cm}^{2}\right)$ & 24.75 & 32.53 & 35.45 & 33.45 & 8.24 & 0.48 \\
\hline Heart weight (g) & 168.8 & 192.9 & 196.8 & 165.7 & 10.53 & 0.29 \\
\hline Liver weight (g) & 378.1 & 420.6 & 455.5 & 438.1 & 29.54 & 0.34 \\
\hline Lung weight (g) & 398.8 & 367.9 & 360.7 & 372.4 & 18.21 & 0.65 \\
\hline Kidney weight (g) & 73.05 & 82.95 & 83.30 & 70.70 & 3.76 & 0.51 \\
\hline
\end{tabular}

SEM, pooled standard error of the means.

1) Each mean represents 3 replications with 1 sheep per replication.

${ }^{2)}$ CON, control diet; TAN, CON+0.1\% tannins (95\% purity); CEL, CON+0.1\% cellulose $(15,000 \mathrm{IU} / \mathrm{g})$; TAN+CEL, CON+0.1\% tannins and $0.1 \%$ cellulase.

${ }^{a-c}$ Mean values within a row marked with different superscript letters differ significantly at $p<0.05$.

pared with CON but did not ( $\mathrm{p}>0.05)$ differ from TAN or CEL groups. The backfat thickness of TAN was lower $(\mathrm{p}<0.05)$ than that of CON. No significant differences were found ( $p>$ 0.05 ) for eye muscle area or weight of heart, liver, lungs, and kidneys.

\section{DISCUSSION}

It has been generally accepted that tannins might cause a reduction of daily feed intake and weight gain [14]. However, FBW, ADG, ADFI, and F/G were not affected by tannins supplementation alone in current study. A meta-analysis study indicated that tannins did not have negative effect on DM intake or live weight change in growing sheep, which was consistent with results in the present study [15]. Compared with $\mathrm{CON}$, the cellulase supplementation alone increased FBW and ADG, but reduced F/G in the current study. Similarly, calves fed cellulase had higher FBW, ADG and feed efficiency [5]. The mixture of tannins and cellulase increased FBW and ADG compared with CON in the present study. However, the sheep fed tannins and cellulase together had lower FBW than those fed cellulase alone. The results suggested that the cellulase supplementation alone improved growth performance but tannins may partly interfer.

As is well known, tannins have an ability to complex with protein to protect it against ruminal degradation, and the protection was more effective for proteins than DM or other nutrients [16]. In the present study, tannins supplementation alone increased DM digestibility and decreased CP digestibility. Similarly, it is noted that quebracho tannin extract in diets decreased apparent digestibility of CP in cattle [17]. However, pervious researches also showed that tannins supplementation would decrease DM digestibility in ruminants [15]. These inconsistent results might be attributed to the different origins of tannins, which vary greatly in their capacity to bind carbohydrates [18]. The increased digestibility of DM and CF noted with cellulase supplementation alone in the current study agreed with the results of other studies. It is found that lambs fed exogenous cellulase diets had greater $\mathrm{DM}$ and CF digestibility than those fed non-cellulase diets [5]. In vitro research also proved that exogenous cellulase supplementation alone increased substrate fiber degradation, volatile fatty acid production, and ruminal microbial growth to enhance rumen fermentation [19]. This improvement could ultimately increase DM and CF digestibility and might partly explain the increase of $\mathrm{ADG}$ and reduction of F/G. The mixture of tannins and cellulase supplementation increased DM and CF digestibility compared with CON and had greater CP digestibility than tannins group. As mentioned above, the results indicated that tannins in the present study might not inactivate the cellulase, and the effect of cellulase could partially counteract the reduction of CP digestibility by tannins.

Serum TP was a marker of nutritional level and was increased by tannins and cellulase in present study [20]. The results revealed that liver protein synthesis and rumen microbial protein production might be improved by tannins and cellulase, even when the $\mathrm{CP}$ digestibility was decreased by tannins. Similarly, previous study found that supplementing lambs' diets with fiberolytic enzymes significantly increased serum TP compared with CON [21]. Furthermore, the mixture of tannins and cellulase had greater serum TP than other treatments. As mentioned above, tannins and cellulase together increased CP digestibility compared with tannins alone and the cellulase could eliminate the side effect of tannins on the CP digestibility, which might contribute to the higher serum TP. Therefore, the results suggested that the improvement of serum TP may be enhanced by the interaction of tannins and cellulase. Moreover, the increased serum GLB contributed to the increase of serum TP and decrease of $A / G$ in the current study. Serum GLB played an important role in immune system and the increased GLB could enhance 
humoral immune response against pathogenic viruses and microorganisms [22]. Therefore, the increased serum GLB indicated that tannins, cellulase and the mixture could improve immunity of sheep. Besides, the ALP was increased by tannins, cellulase and the mixture, which played an integral role in metabolism within the liver and development within the skeleton [23]. The results revealed that liver function and skeleton development might be improved by tannins and cellulase. However, the GLB and ALP were not increased by the mixture compared with tannins or cellulase alone. The results indicated that there was not a synergy between tannins and cellulase on improving serum GLB and ALP.

In the present study, the mixture of tannins and cellulase increased carcass weight and dressing percentage compared with $\mathrm{CON}$, which indicated that the addition of tannins and cellulase together could improve slaughter carcass characteristics. On the contrary, feeding xylanase and cellulase had no effect on hot carcass weight and dressing percentage of steers [24]. Tannins in birdsfoot trefoil did not affect carcass weight or dressing-out of lambs [25]. The differences might be due to different species and tannins origins. Besides, the backfat thickness was decreased by tannins alone. Similarly, finishing steers fed high-tannin sorghum diets had lower backfat thickness than CON [26]. The results illustrated that tannins had adverse effect on backfat and the cellulase could eliminate the side effect. The tannins and cellulase increased liver, heart and kidney weight numerically, which was consistent with previous study [21]. The results showed that the mixture of tannins and cellulase might promote organs development, which may have contributed to increased ADG and the changes in blood profiles.

The $\mathrm{VH}, \mathrm{CD}$, and $\mathrm{VH}: \mathrm{CD}$ ratio are markers of bowel integrity and increase during development [27]. In the present study, the CD of jejunum was decreased and VH:CD was increased by tannins. However, feeding $0.5 \%$ quebracho tannin induced ulceration and an increase in mucosal histiocytes in the jejunum and ileum of sheep [28]. The differences might be due to the higher tannins content in their diets compared with the present study. Our results indicated that $0.1 \%$ tannins could promote jejunum development. The cellulase increased VH of jejunum and ileum and VH:CD of jejunum, but decreased $\mathrm{VH}$ of jejunum in the current study. The results indicated cellulase could promote jejunum and ileum development and ultimately improve nutrient digestion and absorption, which may contribute to the higher ADG and feed efficiency $[27,29]$. The mixture of tannins and cellulase also decreased $\mathrm{VH}$ of jejunum, but increased $\mathrm{VH}$ and $\mathrm{VH}: \mathrm{CD}$ of jejunum, especially the VH of ileum. The results suggested that there was a synergy between tannins and cellulase on the development of ileum. However, no significant differences in the $\mathrm{CD}$ or $\mathrm{VH}: \mathrm{CD}$ was found for the ileum, illustrating that the morphology of the jejunum was more easily affected by tannins and cellulase than that of the ileum during growth [27].

\section{CONCLUSION}

The tannins supplementation alone increased ATTD of DM, serum GLB and TP, CD, and VH:CD of jejunum, but decreased ATTD of CP and backfat thickness. The cellulase supplementation alone increased ADG, feed efficiency, ATTD of DM and CF, serum TP, GLB, and ALP, VH and VH:CD of jejunum and $\mathrm{VH}$ of ileum, while decreased serum A/G and $\mathrm{CD}$ of jejunum. The mixture of tannins and cellulase improved ATTD of CP, serum TP and CD of ileum, but decreased FBW compared with tannins or cellulase alone. The results illustrated that although CP digestibility and FBW may be negatively affected by tannins, the mixture of tannins and cellulase might promote nutrient digestion, liver protein synthesis and intestinal development and thus improved growth performance and carcass characteristics.

\section{CONFLICT OF INTEREST}

We certify that there is no conflict of interest with any financial organization regarding the material discussed in the manuscript.

\section{ACKNOWLEDGMENTS}

This study was supported by the National Natural Science Foundation of China (31460620) and the Science and Technology Development Projects of Jilin Province (2018041 2047XH).

\section{REFERENCES}

1. Walton J, Waghorn G, Plaizier J, et al. Influence of condensed tannins on gut morphology in sheep fed Lotus pedunculatus. Can J Anim Sci 2001;81:605-7. https://doi.org/10.4141/A01040

2. Bunglavan S, Dutta N. Use of tannins as organic protectants of proteins in digestion of ruminants. J Livest Sci 2013;4:6777.

3. Stewart EK, Villalba JJ, Rood KA. Environmental and animal benefits when beef cattle consume condensed and hydrolysable tannins. All Current Publications 2018; Paper 1858. Available from: https://digitalcommons.usu.edu/extension_curall/1858/

4. Jayanegara A, Goel G, Makkar HPS, Becker K. Divergence between purified hydrolysable and condensed tannin effects on methane emission, rumen fermentation and microbial population in vitro. Anim Feed Sci Technol 2015;209:60-8. https://doi.org/10.1016/j.anifeedsci.2015.08.002

5. Titi HH, Tabbaa MJ. Efficacy of exogenous cellulase on digesti- 
bility in lambs and growth of dairy calves. Livest Prod Sci 2004;87:207-14. https://doi.org/10.1016/j.livprodsci.2003.07. 012

6. Bhasker TV, Nagalakshmi D, Rao DS. Development of appropriate fibrolytic enzyme combination for maize stover and its effect on rumen fermentation in sheep. Asian-Australas J Anim Sci 2013;26:945-51. https://doi.org/10.5713/ajas.2012. 12590

7. McSweeney C, Palmer B, Bunch R, Krause DO. Effect of the tropical forage calliandra on microbial protein synthesis and ecology in the rumen. J Appl Microbiol 2001;90:78-88. https:// doi.org/10.1046/j.1365-2672.2001.01220.x

8. Olsen SN, Bohlin C, Murphy L, et al. Effects of non-ionic surfactants on the interactions between cellulases and tannic acid: a model system for cellulase-poly-phenol interactions. Enzyme Microb Technol 2011;49:353-9. https://doi.org/10. 1016/j.enzmictec.2011.06.015

9. He L, Zhou W, Wang Y, Wang C, Chen X, Zhang Q. Effect of applying lactic acid bacteria and cellulase on the fermentation quality, nutritive value, tannins profile and in vitro digestibility of Neolamarckia cadamba leaves silage. J Anim Physiol Anim Nutr 2018;102:1429-36. https://doi.org/10.1111/jpn.12965

10. National Research Council. Nutrient requirements of small ruminants. Washington, DC, USA: National Academy Press; 2007.

11.AOAC. Official methods of analysis of AOAC. 17th ed. Gaithersburg, MD, USA: AOAC International; 1995.

12. Holle S, Birtles M. An immunocytochemical method for studying patterns of cell proliferation in the wool follicle. NZ Vet J 1990;38:89-93. https://doi.org/10.1080/00480169.1990.35625

13.McLeod JS, Church JT, Yerramilli P, et al. Gastrointestinal mucosal development and injury in premature lambs supported by the artificial placenta. J Pediatr Surg 2018;53:1240-5. https:// doi.org/10.1016/j.jpedsurg.2018.02.092

14.Salem HB, Nefzaoui A, Makkar HPS, Hochlef H, Ben Salem I, Ben Salem L. Effect of early experience and adaptation period on voluntary intake, digestion, and growth in Barbarine lambs given tannin-containing (Acacia cyanophylla Lindl. foliage) or tannin-free (oaten hay) diets. Anim Feed Sci Technol 2005; 122:59-77. https://doi.org/10.1016/j.anifeedsci.2005.04.014

15.Méndez-Ortiz F, Sandoval-Castro C, Ventura-Cordero J, Sarmiento-Franco LA, Torres-Acosta JFJ. Condensed tannin intake and sheep performance: a meta-analysis on voluntary intake and live weight change. Anim Feed Sci Technol 2018; 245:67-76. https://doi.org/10.1016/j.anifeedsci.2018.09.001

16. Rosenthal GA, Berenbaum MR. Herbivores: their interactions with secondary plant metabolites: ecological and evolutionary processes. Vol. 2. Pittsburgh, PA, USA: Academic Press; 2012.

17. Beauchemin KA, McGinn SM, Martinez TF, McAllister TA. Use of condensed tannin extract from quebracho trees to reduce methane emissions from cattle. J Anim Sci 2007;85: 1990-6. https://doi.org/10.2527/jas.2006-686
18. McAllister TA, Martinez T, Bae HD, Muir AD, Yanke LJ, Jones GA. Characterization of condensed tannins purified from legume forages: chromophore production, protein precipitation, and inhibitory effects on cellulose digestion. J Chem Ecol 2005;31:2049-68. https://doi.org/10.1007/s10886-0056077-4

19. Giraldo LA, Tejido ML, Ranilla MJ, Carro MD. Effects of exogenous cellulase supplementation on microbial growth and ruminal fermentation of a high-forage diet in Rusitec fermenters. J Anim Sci 2007;85:1962-70. https://doi.org/10.2527/ jas.2006-318

20.Förhécz Z, Gombos T, Borgulya G, Pozsonyi Z, Prohászka Z, Jánoskuti L. Red cell distribution width in heart failure: prediction of clinical events and relationship with markers of ineffective erythropoiesis, inflammation, renal function, and nutritional state. Am Heart J 2009;158:659-66. https://doi.org/10. 1016/j.ahj.2009.07.024

21.Abutaima A. Utilization of fiberolytic enzymes for improving digestibility in assaf lambs feed [PhD Thesis]. Gaza, Palestine: National Research Centre; 2017.

22. Woof JM, Kerr MA. The function of immunoglobulin A in immunity. J Pathol 2006;208:270-82. https://doi.org/10.1002/ path. 1877

23. Millán JL. Alkaline phosphatases: structure, substrate specificity and functional relatedness to other members of a large superfamily of enzymes. Purinergic Signal 2006;2:335-41. https:// doi.org/10.1007/s11302-005-5435-6

24.ZoBell DR, Wiedmeier R, Olson K, Treacher R. The effect of an exogenous enzyme treatment on production and carcass characteristics of growing and finishing steers. Anim Feed Sci Technol 2000;87:279-85. https://doi.org/10.1016/S03778401(00)00202-9

25.Douglas G, Stienezen M, Waghorn G, Foote AG, Purchas RW. Effect of condensed tannins in birdsfoot trefoil (Lotus corniculatus) and sulla (Hedysarum coronarium) on body weight, carcass fat depth, and wool growth of lambs in New Zealand. NZ J Agric Res 1999;42:55-64. https://doi.org/10.1080/0028 8233.1999.9513353

26.Larraín R, Schaefer D, Arp S, Claus JR, Reed JD. Finishing steers with diets based on corn, high-tannin sorghum, or a mix of both: Feedlot performance, carcass characteristics, and beef sensory attributes. J Anim Sci 2009;87:2089-95. https://doi.org/10.2527/jas.2007-0433

27.Li H, Ran T, He Z, Yan Q, Tang S, Tan Z. Postnatal developmental changes of the small intestinal villus height, crypt depth and hexose transporter mRNA expression in supplemental feeding and grazing goats. Small Rumin Res 2016;141:10612. https://doi.org/10.1016/j.smallrumres.2016.07.012

28.Dawson JM, Buttery PJ, Jenkins D, Wood CD, Gill M. Effects of dietary quebracho tannin on nutrient utilisation and tissue metabolism in sheep and rats. J Sci Food Agric 1999;79:142330. https://doi.org/10.1002/(SICI)1097-0010(199908)79:11< 
1423::AID-JSFA383>3.0.CO;2-8

29. Meale SJ, Beauchemin KA, Hristov A, Chaves AV, McAllister

TA. Board-invited review: opportunities and challenges in using exogenous enzymes to improve ruminant production. J Anim Sci 2014;92:427-42. https://doi.org/10.2527/jas.20136869 